\title{
Kesehatan Mental Sumber Daya Manusia Indonesia
}

\author{
Dearossi Hani Khoirunissa $^{1}$, Ni Made Sukartini \\ ${ }^{1}$ Magister Ilmu Ekonomi, Fakultas Ekonomi dan Bisnis Universitas Airlangga Surabaya/Badan \\ Pusat Statistik Provinsi Kepulauan Riau; \\ ${ }^{2}$ Fakultas Ekonomi dan Bisnis Universitas Airlangga Surabaya \\ Email corresponding author: dearossi.hani@bps.go.id
}

\begin{abstract}
ABSTRAK
Kesehatan SDM menjadi penting disebabkan oleh peran SDM sebagai input modal bagi perekonomian.Kerugian akibat gangguan kesehatan mental akan berdampak pada gangguan fungsi fisik penderitanya, serta akan menjadi kerugian ekonomi pada wilayahnya. Peneliti menduga terdapat hubungan antara kondisi wilayah terhadap jumlah penderita kesehatan mental. Peneliti berharap agar masalah kesehatan mental dapat dilihat sebagai prioritas dalam merumuskan kebijakan.Penelitian empiris melalui data bersumber dari sumber Podes 2018 oleh BPS. Gambaran cacat mental menunjukkan bahwa wilayah dengan kepadatan penduduk akan menghasilkan jumlah cacat mental yang lebih tinggi. Prevalensi cacat mental menyebar di seluruh wilayah Indonesia. Wilayah Sulawesi memiliki prevalensi cacat mental yang sedang di setiap wilayah. Kejadian pemasungan memiliki pola yang sama dengan jumlah cacat mental dengan kejadian terbanyak di provinsi NTT. Semakin sulit topografi wilayah maka akan semakin banyak kasus pemasungan yang terjadi. Metode OLSdengan menggunakan robust standart errormenunjukkan bahwa pengaruh lingkungan fisik seperti topografi tidak terlalu berpengaruh pada jumlah cacat mental, namun pencemaran dan permukiman kumuh berpengaruh positif terhadap jumlah cacat mental.
\end{abstract}

Kata Kunci: cacat mental, pasung, desa, Podes 2018, SIG,OLS

\section{PENDAHULUAN}

Tujuan pembangunan dalam MDGs sebagian besar lebih menitikberatkan pada pengentasan kemiskinan di seluruh dunia dengan goal akhir pada tahun 2015. Petinggi negara di berbagai dunia kembali merumuskan tujuan pembangunan dalam Sustainable Development Goals (SDGs) pada akhir 2015. Pembangunan menurut SDGs dilandasi atas kesadaran bahwa kemiskinan dapat diakhiri jika pembangunan yang dilakukan berkelanjutan tanpa melupakan pembangunan manusia di dalamnya.

Kualitas SDM sebagai bentuk pembangunan manusiadalam ekonomi dinilai ke dalam tiga indikator. Ketiga indikator tersebut yaitu Pendidikan, Ekonomi, dan Kesehatan(United Nations Development Programme, 2019).Kesehatan SDM menjadi penting disebabkan oleh peran kesehatan SDM sebagai modal bagi perekonomian dalam bentuk tenaga kerja. Fungsi Produksi sederhana:

$$
q=f(k, l)
$$

menyatakan bahwa besaran produksi $(q)$ akan dipengaruhi oleh dua modal yaitu $\operatorname{kapital}(k)$ dan tenaga kerja (l)(Nicholson \& Snyder, 2012).Pembangunan manusia dalam bentuk investasi dalam pendidikan dan pelatihan keterampilan akan menjadi penguat proses pertumbuhan ekonomi (Bucciarelli, Odoardi, \& Muratore, 2010). Semakin baik tenaga kerja sebagai bentuk modal manusia akan mendorong manusia untuk meningkatkan produktivitas dan stabilitas sosial 
mendorong pertumbuhan ekonomi (Becker, Murphy, \& Tamura, 1990; Denison, 1962; Schultz, 1961). Input tenaga kerja juga penting dan berpengaruh pada pengembalian saham(Rong, Tian, Li, \& Zheng, 2020).

Target pembangunan terkait kesehatan mental menempatkan individu sebagai kelompok yang rentan(Funk et al., 2010). SDM yang memiliki masalah kesehatan akan memberikan dampak yang buruk bagi perekonomian. Masalah kesehatan mental akan menyebabkan penderitanya kurang efektif bekerjadalam bentuk absenteeism dan presenteeism bahkan berakhir menjadi pengangguran. Laki-laki dengan gangguan mental akancenderung keluar masuk keluar dan akhirnya menjadi pengangguran, sementara wanita cenderung keluar masuk dengan berganti-ganti pekerjaan (Gresenz \& Sturm, 2004; Layard, 2016).

Kesehatan mental dan kemiskinan dihubungkan oleh ketimpangandan memiliki hubungan yang kuat pada negara berpenghasilan rendah. Dampak yang terjadi antara lainfragmentasi sosial,peningkatan tunawisma, tingkat kriminalitas, dan berkurangnya lapangan kerja serta penurunan pendapatan. Penyakit mental akan menyebabkan pemborosan ekonomi dikarenakan penyakit ini sebagian besar terjadi pada penduduk yang berusia kerja(Burns, 2015; Funk, Drew, \& Knapp, 2012).

Pada tahun 2010, gangguan penggunaan mental dan zat merupakan 10,4\% dari beban penyakit global dan merupakan penyebab utama tahun hidup dengan kecacatan di antara semua kelompok penyakit. Penyakit mental diproyeksikan menyebabkan kerugian ekonomi sebesar 16,3 triliun USD di seluruh dunia di antara tahun 2011 hingga 2030. Kerugian ini akan sebanding dengan dampak penyakit kardiovaskular dan lebih tinggi daripada kanker, penyakit pernafasan kronis dan diabetes (Trautmann, Rehm, \& Wittchen, 2016).Penelitian sejenis mengenai beban penyakit mental Schizophrenia di Aceh tahun 2016 sebesar 19,52 miliar Rupiah atau setara dengan 1,02\% dari kerugian ekonomi kesehatan mental di seluruh Indonesia (Isnaini, Abdullah, \& Saputra, 2019).

Penurunan prevalensi kejadian kesehatan mental dari data Survei Riskesdas tahun $2007 \mathrm{ke}$ 2013 merupakan sebuah anomali yang berkebalikan dengan kenyataan di lapangan (Ridlo, 2017). Hasil tersebut berbanding terbalik dengan hasil Riskesdas tahun 2018. Gambar 1 menunjukkan bahwa terjadi peningkatan prevalensi rumah tangga yang memiliki anggota dengan gangguan jiwa. Gangguan jiwa yang dicakup hanya Skizofrenia/Psikosis. Data tersebut dihasilkan dari Survei Riset Kesehatan Dasar (Riskesdas) oleh Kementerian Kesehatan Republik Indonesia. Peningkatan prevalensi dalam 5 tahun terjadi di seluruh provinsi secara merata, dengan prevalensi tertinggi di Provinsi Bali dan terendah di Provinsi Kepulauan Riau. 


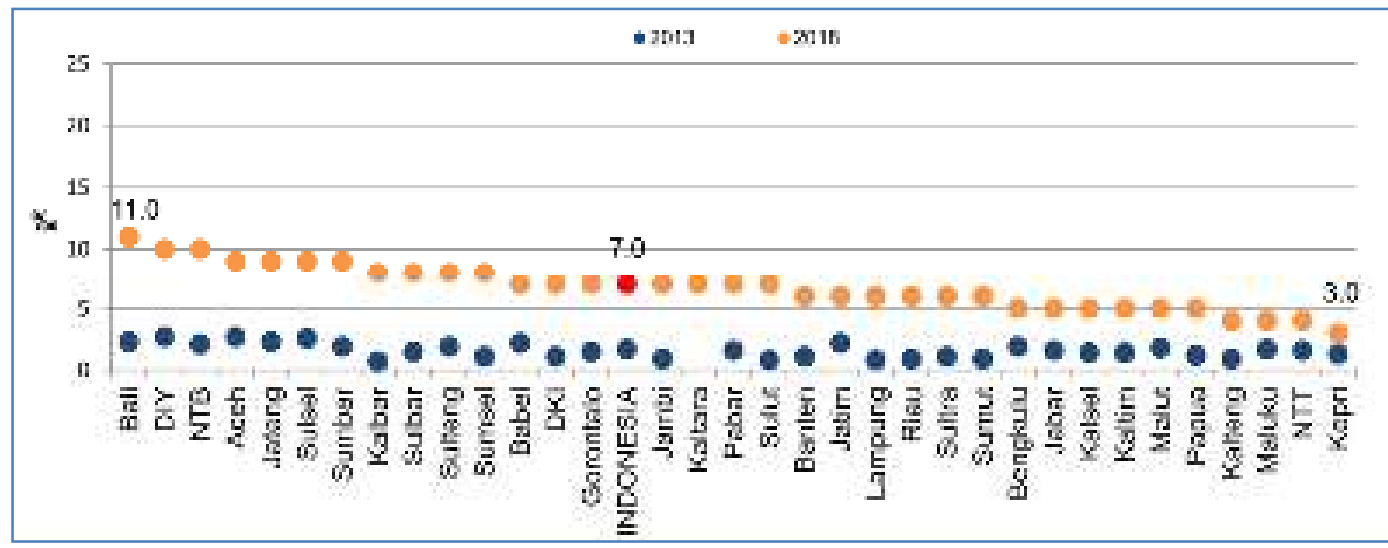

Gambar 1. Prevalensi Rumah Tangga dengan ART Gangguan Jiwa Skizofrenia/Psikosis, 2013-2018

Sumber : Kementerian Kesehatan Republik Indonesia

Kerugian akibat gangguan kesehatan mental juga akan berdampak pada gangguan fungsi fisik penderitanya(Dewi, 2012). SDM yang memiliki kekurangan pada fisik (disabilitas) juga akan berpengaruh pada kualitas SDM tersebut. Penyandang disabilitas memiliki tingkat partisipasi pekerjaan yang lebih rendah dibandingkan dengan yang bukan penyandang disabilitas, serta memiliki kerentanan terhadap keberlangsungan pekerjaan.Penyandang disabilitas juga akan menghadapi diskriminasi, ketidakpastian dan kurangnya pengakuan dari pemberi pekerjaan (Mizunoya \& Mitra, 2013; Vedeler, 2014). Perlu adanya kebijakan dan dukungan dari pemerintah dalam meningkatkan kualitas psikososial pekerjaan bagi penyandang disabilitas(Milner et al., 2015).

Kesehatan mental menjadi penting karena dapat memberikan berbagai efek negatif bagi perekonomian. Mayoritas negara berkembang, termasuk Indonesia, masih menganggap gangguan kesehatan mental sebagai low priority issue dengan memberikan kebijakan kuratif dibandingkan kebijakan preventif, promotif dan rehabilitatif(Ridlo, 2017). Di sisi lain, kesehatan mental telah masuk dalam indikator SDGsyang juga diadopsi ke dalam Tujuan Pembangunan Berkelanjutan (TPB) di Indonesia.

Pembangunan terkait kesehatan diwujudkan dalam Tujuan Ketiga dalam SDGs yaitu "Ensure healthy lives and promote well-being for all at all ages" atau "Menjamin Kehidupan yang Sehat dan Meningkatkan Kesejahteraan Seluruh Penduduk Semua Usia”. Indikator yang mencakup kesehatan mental terdapat pada Indikator 3.4 yaitu pada tahun 2030 mengurangi hingga sepertiga angka kematian dini akibat penyakit tidak menular, melalui pencegahan dan pengobatan, serta meningkatkan kesehatan mental dan kesejahteraan. Kesehatan mental termasuk dalam penyakit non-communicable diseases atau penyakit yang tidak menular. Namun, indikator tersebut di Indonesia masih terbatas pada kebijakan kuratif dengan kepemilikan puskesmas dengan penyelenggaraan upaya kesehatan jiwa di setiap kabupaten/kota.

Peneliti merasa diperlukan adanya penelitian yang dapat mengukur beberapa variabel yang diduga dapat mempengaruhi besaran jumlah penyandang kesehatan mental di wilayah administrasi terkecil, yaitu perdesaan. Penelitimenduga terdapat hubungan antara kondisi wilayah terhadap jumlah penderita kesehatan mental. Penelitian ini dapat menjadi masukan bagi pemerintah dalam mempertimbangkan pentingnya perhatian terkait kesehatan mental, serta agar masalah kesehatan mental dapat dilihat sebagai prioritas dalam merumuskan kebijakan. 


\section{TINJAUAN PUSTAKA}

\subsection{Ekonomi Kesehatan}

Santerre \& Neun (2010) menyatakan bahwa studi ekonomi kesehatan mencakup berbagai aplikasi ilmu mikroekonomi, seperti teori permintaan, teori biaya, hingga pada masalah-masalah kesehatan itu sendiri. Namun, studi ekonomi kesehatan sangat berguna dalam memberikan pemahaman yang lebih baik tentang aspek ekonomi dari masalah perawatan kesehatan sehingga kebijakan kesehatan dapat dirancang dan diterapkan. Ekonomi kesehatan merupakan studi yang mempelajari penawaran dan permintaan sumber daya layanan kesehatan dan dampak sumber daya layanan kesehatan pada populasi.

Becker menjelaskan mengenai Health Belief Model (HBM) yang dikaitkan dengan Personal Health Behaviour. Dalam penelitian ini HBM merupakan konsep untuk memahami penyebab tindakan individu secara psikologis terkait tindakan kesehatan yang akan diambilnya (Janz \& Becker, 1984). Janz dan Becker dalam penelitian lanjutannya memberikan pertimbangan kepada pemerintah agar HBM menjadi bagian dari kebijakan pendidikan kesehatan. Peneliti tersebut juga menyarankan untuk dilakukan penelitian yang lebih lanjut mengenai pendidikan kesehatan.

Keterkaitan antara ilmu ekonomi dengan kesehatan diungkapkan oleh Michael Grossman pada tahun 1972 dengan menggambarkan model dasar untuk utilitas kesehatan individu tergantung kesehatannya dan barang non-kesehatan yang dikonsumsi (Grossman, 1972). Utilitas individu untuk periode $t$ digambarkan dalam model:

$$
U_{t}=U\left(H_{t}, Z_{t}\right)
$$

dimana $U_{t}$ adalah utilitas individu untuk periode $t ; H_{t}$ adalah tingkat kesehatan; dan $Z_{t}$ adalah barang komposit (barang rumah tangga) yang mencakup fungsi utilitas yang disesuaikan dengan baik. Dalam fungsi 1, perawatan kesehatan tidak muncul secara eksplisit sehingga perawatan kesehatan yang diterima dapat memengaruhi utilitas melalui tingkat kesehatan $H$. $H$ dan $Z$ merupakan kontributor yang berbeda bagi fungsi utilitas. Pilihan individu secara bersamaan dapat mengubah $H$ dan $Z$ dan menimbulkan tradeoff. Pilihan individu untuk memilih gaya hidup tidak sehat, akan dapat berkontribusi positif terhadap $Z$, namun dapat menurunkan $H$. Sebaliknya, pilihan individu untuk berolahraga akan bersamaan dapat meningkatkan $H$ dan $Z$.

Grossman juga membangun sebuah model komoditas kesehatan yang baik dengan output berupa waktu kesehatan, dimana kesehatan bagi seorang individu diumpamakan sebagai saham dan akan terdepresiasi seiring bertambahnya usia dan akan bertambah jika individu tersebut berinvestasi. Variabel yang mempengaruhi investasi tersebut disebut sebagai shadow price/harga bayangan yang terdiri dari beberapa faktor, tidak hanya harga perawatan kesehatan secara medis, namun juga faktor lain seperti pendidikan dan siklus hidup individu tersebut.

Bhattacharya et al. (2014)menyatakan bahwa pemahaman mengenai ekonomi pasar kesehatan akan memberikan wawasan yang mendalam tentang fungsi dan pertukaran (tradeoff) penyediaan kesehatan masyarakat. Peneliti tersebut menyimpulkan dari penelitiannya di Amerika Serikat bahwa pentingnya ekonomi kesehatan (health economics) yang disebabkan oleh tiga faktor. Pertama, ekonomi perawatan kesehatan sangat besar dan mahal. Sekitar 16,67\% atau satu dari enam dolar uang yang dimiliki akan dihabiskan untuk perawatan kesehatan pada tahun 
2008. Nilai ini melonjak dibandingkan dengan tahun 1960 dimana warga hanya menghabiskan kurang dari satu dolar dari setiap dua puluh dolar yang dimiliki untuk perawatan kesehatan. Kenaikan ini juga disebabkan kesadaran masyarakat bahwa perawatan kesehatan tentu dapat memperpanjang masa hidup dan meningkatkan kualitas hidup.

Kedua, kesehatan penuh dengan ketidakpastian dan eksternalitas. Profesor Kenneth Arrow tahun 1963 dalam Bhattacharya et al. (2014) berpendapat bahwa kesehatan berbeda dari barang lain karena ketidakpastian yang dimilikinya. Kebutuhan akan jumlah barang ekonomi lain dapat diperkirakan oleh manusia, namun kesehatan seperti kejadian kecelakaan atau serangan jatung tidak akan dapat diperkirakan, sehingga dapat tiba-tiba menciptakan permintaan untuk layanan perawatan kesehatan yang mahal. Ketidakpastian kesehatan akan memotivasi terciptanya asuransi kesehatan. Pasar asuransi aneh karena adanya asimetri informasi antara pembeli dan penjual. Asimetri informasi dapat terjadi karena terkait dengan besar kecilnya biaya pertanggungan dapat dicover oleh penjual asuransi. Pasar perawatan kesehatan juga dipenuhi dengan eksternalitas karena kesehatan memiliki kemampuan untuk menular. Keputusan kesehatan satu orang dapat mempengaruhi kesehatan orang lain, begitupun sebaliknya. Fenomena ini dapat merusak fungsi pasar yang efisien.

Ketiga, pemerintah di seluruh dunia pasti sangat terlibat dalam pembiayaan sistem perawatan kesehatan. Setelah Perang Dunia II, lebih banyak pemerintah negara di dunia yang terlibat dalam pasar perawatan kesehatan. Fenomena tersebut diiringi dengan banyaknya negara yang memperkenalkan program asuransi baru yang dibiayai pemerintah. Tekanan pada pemerintah untuk membiayai biaya perawatan kesehatan akan meningkat dalam beberapa dekade mendatang. Meningkatnya harapan hidup dan populasi yang menua di seluruh negara maju akan memberi tekanan besar pada sistem asuransi kesehatan publik yang bertanggung jawab untuk membayar perawatan kesehatan. Tren tersebut akan menjadikan item perawatan kesehatan menjadi terus tumbuh di neraca pemerintah.

Bloom et al. (2011)menunjukkan bahwa melalui EPIC tool dapat mensimulasikan beban ekonomi yang berasal dari penyakit tidak menular (Non-Communicable Diseases/NCD) terhadap output ekonomi agregat. EPIC tool dibangun oleh WHO dengan menghitung kerugian output akibat penyakit di beberapa negara spesifik. Perhitungan dilakukan dengan menggunakan nilai dollar pada daya beli masyarakat yang disesuaikan (Purchasing Power Parity-PPP) dengan basis tahun 1997. Perhitungan EPIC diperbesar skalanya secara global dengan menggunakan data Tahun Penyesuaian Disabilitas (Disability-Adjusted Life Year/DALY) dari WHO mengenai penyakit jiwa. Sehingga, akan didapatkan perkiraan kerugian ekonomi dari kondisi kesehatan mental.

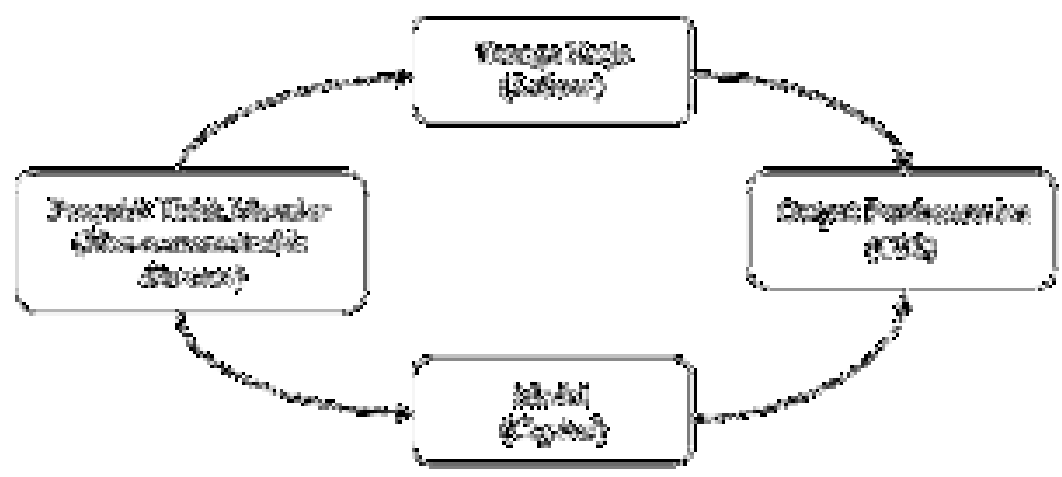


Gambar 2. Kinerja EPIC Tool menurut Bloom et al.

EPIC tool menggunakan model pertumbuhan ekonomi standar yang menghubungkan output agregat dengan input modal dan tenaga kerja. Alat ini menggunakan persamaan produksi sebagaimana variabel teknologi menghubungkan antaar input modal dan tenaga kerja. NCD dimasukkan ke dalam model dengan mengasumsikan NCD menghabiskan modal dan tenaga kerja. Modal dihabiskan dengan pengalihan tabungan dari peningkatan modal fisik ke konsumsi perawatan kesehatan yang terkait dengan NCD. Tenaga kerja dapat berkurang oleh mortalitas dan morbiditas akibat adanya NCD. Beban ekonomi yang diakibatkan oleh NCD dapat diimplementasikan ke dalam tiga metode yang telah dikembangkan oleh para ekonom, yaitu pendekatan biaya penyakit (Cost of Illness/COI); nilai output yang hilang/pendekatan pertumbuhan ekonomi; dan pendekatan nilai kehidupan statistik (Value of Statistical Life-VSL).

Trautmann et al.(2016) dengan menggunakan model yang sama dengan penelitian Bloom et al. menemukan bahwa kesehatan mental dengan perekonomian memiliki keterkaitan yang sangat kuat. Nilai kerugian secara ekonomi (economic costs) yang dihasilkan oleh kesehatan mental bernilai lebih besar dibandingkan dengan penyakit kronis seperti kanker atau diabetes. Salah satu penilaian economic cost melalui besaran tindakan dan perawatan yang dilakukan terhadap penderita penyakit mental. Perawatan kesehatan untuk untuk gangguan mental dan penggunaan zat adiktif memiliki kesenjangan yang lebih tinggi daripada untuk sektor kesehatan lainnya.

\section{METODE PENELITIAN}

\subsection{Definisi Variabel}

Penggunaan variabel pada penelitian didasarkan pada determinan sosial yang berpengaruh bagi kesehatan mental menurut WHO. Determinan sosial tersebut terbagi menjadi lima indikator yaitu Perjalanan Hidup (Life Course); Perilaku/Sikap Pengasuhan Anak (Parenting Behaviours/Attitudes); Komunitas (Community); Layanan Lokal (Local Services); dan Faktor Level Negara (Country Level Factors) (World Health Organization \& Calouste Gulbenkian Foundation, 2014).

WHO mendefinisikan kesehatan mental sebagai keadaan setiap individu yang dapat menyadari potensi dalam dirinya, dapat mengatasi tekanan kehidupan yang normal, dapat bekerja secara produktif dan mampu memberikan kontribusi pada komunitasnya. Penelitian ini menggunakan variabel jumlah penyandang cacat mental dan jumlah orang dipasung sebagai wujud dari gangguan kesehatan mental. Penggunaan variabel jumlah orang yang dipasung didasarkan pada kejadian pemasungan yang identik dilakukan bagi orang dengan gangguan jiwa. Variabel yang digunakan dalam penelitian ini didefinisikan sebagai berikut:

1) Jumlah penderita cacat mental, terdiri atas cacat mental tunagrahita (keterbelakangan mental/jiwa);tunalaras (gangguan pengendalian emosi dan control sosial, termasuk eks sakit jiwa); dan cacat ganda (cacat mental dan fisik).

2) Jumlah orang dipasung.

3) Sumber mata pencaharian utama, yang terbagi menjadi Pertanian dan Non-Pertanian. 
4) Kondisi geografis wilayah, terdiri atas topografi wilayahdan keberadaan wilayah terhadap hutan.

5) Kondisi lingkungan, terdiri atas keberadaan pemukiman kumuh dan pencemaran/polusi.Pencemaran/ polusi terdiri atas pencemaran air, tanah dan udara.

6) Komunitas, terdiri atas keberadaan pekerja seks komersial (PSK), jumlah penderita gizi buruk (marasmus dan kwashiorkor) dan keberagaman suku.

7) Infrastruktur, terdiri atas jumlah fasilitas kesehatan dan jumlah tenaga kesehatan.

\subsection{Data}

Penelitian ini merupakan penelitian empiris yang didasarkan pada data yang mewujudkan kenyataan di lapangan. Data yang digunakan dalam penelitian ini merupakan data sekunder dari Badan Pusat Statistik (BPS) yang meliputi seluruh wilayah Indonesia pada tahun 2018. Data didapatkan dari publikasi BPS dan hasil Survei Potensi Desa (Podes) 2018. Podes tahun 2018 mencakup seluruh wilayah administrasi pemerintahan di 34 provinsi yang terdiri dari 514 kabupaten/kota, 7.480 kecamatan, sehingga didapatkan wilayah setingkat desa sebanyak 94.573. Penelitian ini hanya mencakup wilayah setingkat desa, yang terdiri atas Desa, Kelurahan, SPT/UPT dan Nagari. Wilayah yang termasuk dalam kategoriJurong tidak dimasukkan dalam penelitian dikarenakan struktur pertanyaan yang berbeda pada survei Podes. Sehingga, sampel yang didapatkan hanya sebesar 83.931 observasi.

\subsection{Sistem Informasi Geografis}

Deskripsi setiap variabel bebas dalam penelitian ini akan digambarkan menggunakan sistem informasi geografis (SIG). SIG digunakan pada peta seluruh wilayah Indonesia dengan menggunakan aplikasi ArcView GIS 3.3. Peta dikolaborasikan dengan data yang didapatkan dari Survei Podes 2018 secara kumulatif pada level provinsi.

\subsection{Model OLS}

Penentuan model menggunakan regresi linear klasik dengan metode ordinary least square (OLS), dengan fungsi persamaan:

$$
\mathbf{Y}=\mathbf{f}(\text { determinan sosial kesehatan mental) ....... }
$$

Dengan model yang terbentuk adalah:

$$
\begin{aligned}
& Y_{i}=\beta_{1}+\beta_{2} D_{1 i}+\beta_{3} D_{2 i}+\beta_{4} D_{3 i}+\beta_{5} D_{4 i}+\beta_{6} D_{5 i}+\beta_{7} D_{6 i}+\beta_{8} D_{7 i}+\beta_{9} D_{8 i}+\beta_{10} D_{9 i} \\
& +\beta_{11} X_{1 i}+\beta_{12} X_{2 i}+\beta_{13} X_{3 i}
\end{aligned}
$$

Dimana $Y_{i}$ sebagai variabel dependenadalah jumlah penyandang cacat mental yang terdiri atas: $\mathrm{Y}_{1}$ tunagrahita; $\mathrm{Y}_{2}$ tunalaras; $\mathrm{Y}_{3}$ cacat ganda; dan $\mathrm{Y}_{4 j} \mathrm{jumlah}$ orang dipasung. $\beta_{\mathrm{i}}$ merupakan koefisien persamaan yang terbentuk.

Beberapa variabel independen yang digunakan merupakan variabel yang berskala nominal, sehingga ditransformasikan ke dalam bentuk dummy. Variabel independen terdiri atas:

1) $\mathrm{D}_{1}=$ dummy sumber mata pencaharian utama penduduk desa. Bernilai 1, jika sumber mata pencaharian utama merupakan pertaniandan bernilai 0 , jika non-pertanian 
2) $\mathrm{D}_{2}=$ dummy topografi wilayah perdesaan. Bernilai 1, jika topografi wilayah perdesaan sebagian besar berada di dataran dan bernilai 0, jika topografi di lembah/lereng/puncak

3) $\mathrm{D}_{3}=$ dummyletak wilayah perdesaan terhadap hutan. Bernilai 1, jika letak wilayah berada di dalam/ di sekitar hutan dan bernilai 0, jika di luar hutan

4) $\mathrm{D}_{4} \quad=$ dummykeberadaan permukiman kumuh. Bernilai 1, jika terdapat permukiman kumuh di wilayah desadan bernilai 0 , jika tidak ada

5) $\mathrm{D}_{5} \quad=$ dummykeberadaan pencemaran air. Bernilai 1, jika terdapat pencemaran airdi wilayah perdesaan dan bernilai 0 , jika tidak ada pencemaran air

6) $\mathrm{D}_{6}=$ dummykeberadaan pencemaran tanah. Bernilai 1, jika terdapat pencemaran tanah di wilayah perdesaan dan bernilai 0 , jika tidak ada pencemaran tanah

7) $\mathrm{D}_{7}=$ dummykeberadaan pencemaran udara. Bernilai 1, jika terdapat pencemaran udara di wilayah perdesaan dan bernilai 0 , jika tidak ada pencemaran udara

8) $\mathrm{D}_{8}=$ dummykeberadaan Pekerja Seks Komersial (PSK). Bernilai 1, jika terdapat PSKdan bernilai 0 , jika tidak ada

9) $\mathrm{D}_{9} \quad=$ dummykeragaman suku. Bernilai 1, jika tidak terdapat keragaman sukudan bernilai 0 , jika terdapat keragaman suku

10) $\mathrm{X}_{1}=$ Jumlah penderita gizi buruk (marasmus dan kwashiokor)

11) $X_{2}=$ Jumlah fasilitas kesehatan di wilayah perdesaan

12) $X_{3}=$ Jumlah tenaga kesehatan di wilayah perdesaan

Penggunaan regresi linear memerlukan pengujian terhadap parameter untuk menguji signifikansi model regresi. Pengujian ini dibagi menjadi dua, yaitu uji serentak model dan uji parsial. Pengujian serentak digunakan untuk mengetahui pengaruh seluruh variabel prediktor secara bersama-sama terhadap variabel respon, dengan menggunakan uji F. Pengujian parsial untuk mengetahui pengaruh variable prediktor secara sendiri-sendiri terhadap variabel respon dengan menggunakan uji t.Teknik OLS dapat menduga koefisien dengan kesaahan pendugaan terkecil dan terbaik atau biasa disebut dengan BLUEestimator (Best Linear Unbiased Estimator). BLUE dapat dicapai dengan memenuhi asumsi klasik regresi linear, yaitu uji normalitas; uji multikolinearitas; dan uji homoskedastisitas.

\section{TEMUAN DAN PEMBAHASAN}

\subsection{Gambaran Cacat Mental di Indonesia}

Akses sistem informasi geografis (SIG) dapat membantu dalam hal pengukuran akses geografis terhadap layanan kesehatan mental secara efektif (Fortney, Rost, \& Warren, 2000; Rahmanti \& Prasetyo, 2012; Riyanto, 2017). Gambar 3 menunjukkan bahwa penyandang cacat mental tersebar di seluruh wilayah Indonesia Namun, jumlah penyandang cacat mental lebih didominasi oleh wilayah bagian barat Indonesia, utamanyawilayah padat penduduk. Tiga provinsi dengan jumlah penyandang cacat mental terbesar di Indonesia berada di provinsi padat penduduk di pulau Jawa. berturut-turut yaituJawa Tengah memiliki jumlah penyandang cacat terbesar di 
Indonesia sebanyak 54.610 orang di antara 34.490 .835 penduduknya;Jawa Timur sebanyak 47.858 orang di antara 39.500.851 penduduk; dan Jawa Barat sebanyak 31.591 orang di antara 48.683.861 penduduk.

Provinsi di luar Jawa yang memiliki jumlah penyandang cacat cukup besar berada di Kawasan Sumatera sebanyak tiga provinsi yaitu Sumatera Utara (13.986 orang),Aceh (13.189 orang), dan Sumatera Barat (11.384 orang). Provinsi lain yang memiliki jumlah penyandang cacat cukup besar yaitu provinsi Nusa Tenggara Timur/NTT (10.842 orang) dan Sulawesi Selatan (10.029 orang). Hampir semua provinsi, kecuali NTT, memiliki jumlah penduduk yang padat. Kepadatan jumlah penduduk diyakini berpengaruh besar pada produksi penyakit mental (Laird, 1973; Schweitzer \& Su, 1977; Williams, 1994). Sementara di sisi lain, penelitian di Irlandia Utara tahun 2016 menunjukkan bahwa kepadatan etnis minoritas yang lebih rendah akan membuat insidenkesehatan mental menjadi lebih tinggi (Bosqui et al., 2017).

Prevalensi atau perbandingan antara jumlah penyandang cacat mental dengan jumlah penduduk setiap provinsi di Indonesia memberikan gambaran yang berbeda.Provinsi dengan prevalensi jumlah penduduk cacat mental terhadap penduduk yang tertinggi berada di Aceh $(0,25 \%)$; Sumatera Barat (0,21\%); NTT (0,20\%); Yogyakarta $(0,20 \%)$; dan Bengkulu $(0,19 \%)$. Beberapa provinsi dengan prevalensi yang cukup besar $(0,14-0,16 \%)$ didominasi pada wilayah Sulawesi.

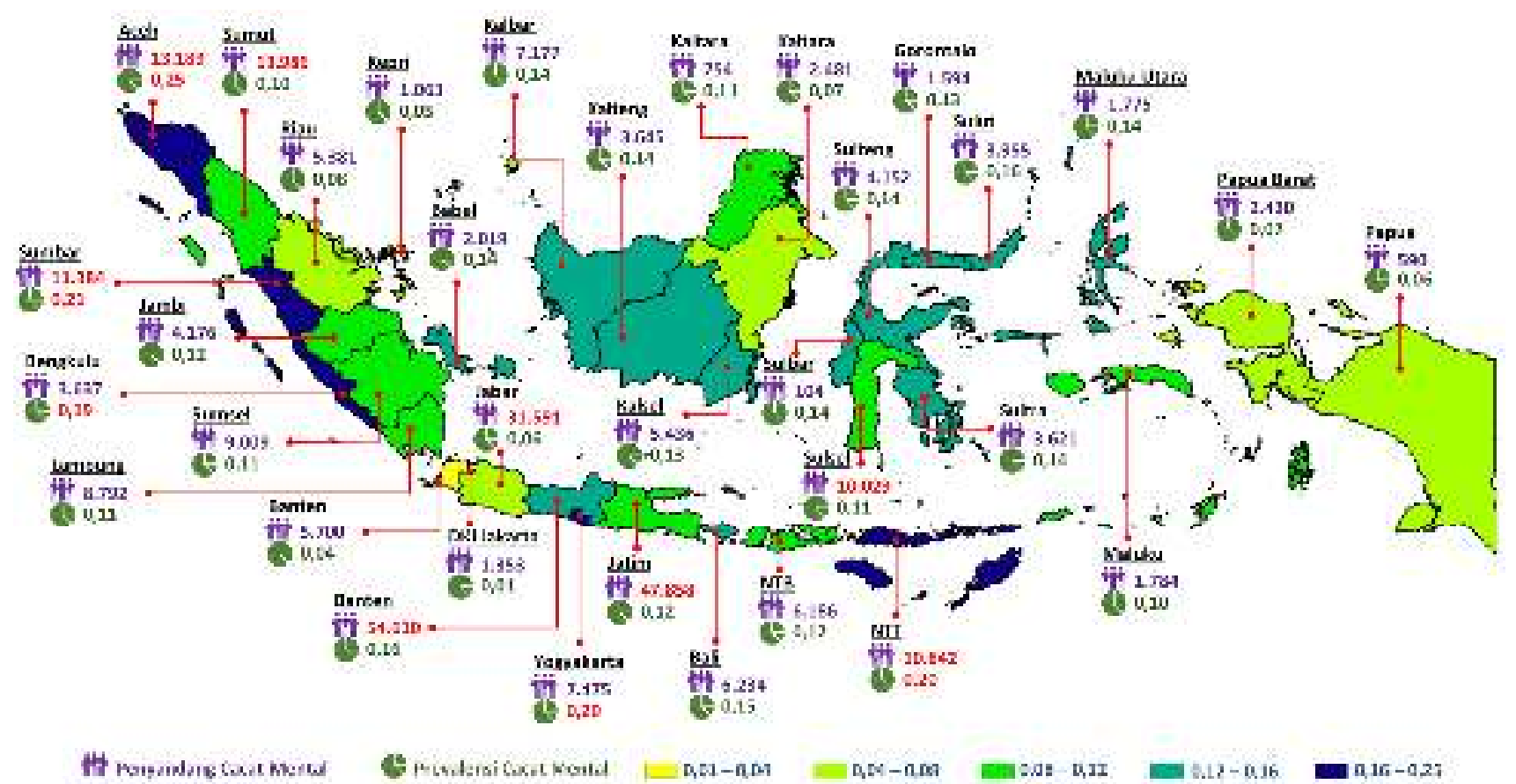

Gambar 3.Jumlah Penyandang dan Prevalensi Cacat Mental Menurut Provinsi Tahun 2018

Perhatian pemerintah mengenai pemasungan tercermin dalam Peraturan Menteri Sosial Nomor 12 tahun 2018 tentang Pedoman Pencegahan dan Penanganan Pemasungan bagi Penyandang Disabilitas Mental. Permensos tersebut dengan tegas melarang adanya tindakan pemasungan bagi penyandang disabilitas mental serta menjadi pedoman bagi penanganan serta tindakan pencegahan pemasungan bagi penyandang disabilitas. Beberapa alasan dilakukan pemasungan bagi ODGJ antara lain: 
1) Ketidaktahuan masyarakat dan pihak keluarga penyandang disabilitas mengenai gangguan jiwa

2) Persepsi negatif dan salah serta rasa malu pihak keluarga penyandang disabilitas

3) Tidak adanya biaya pengobatan bagi ODGJ dan faktor kemiskinan

4) Biaya perawatan kepada psikiatri yang mahal dan berjangka panjang

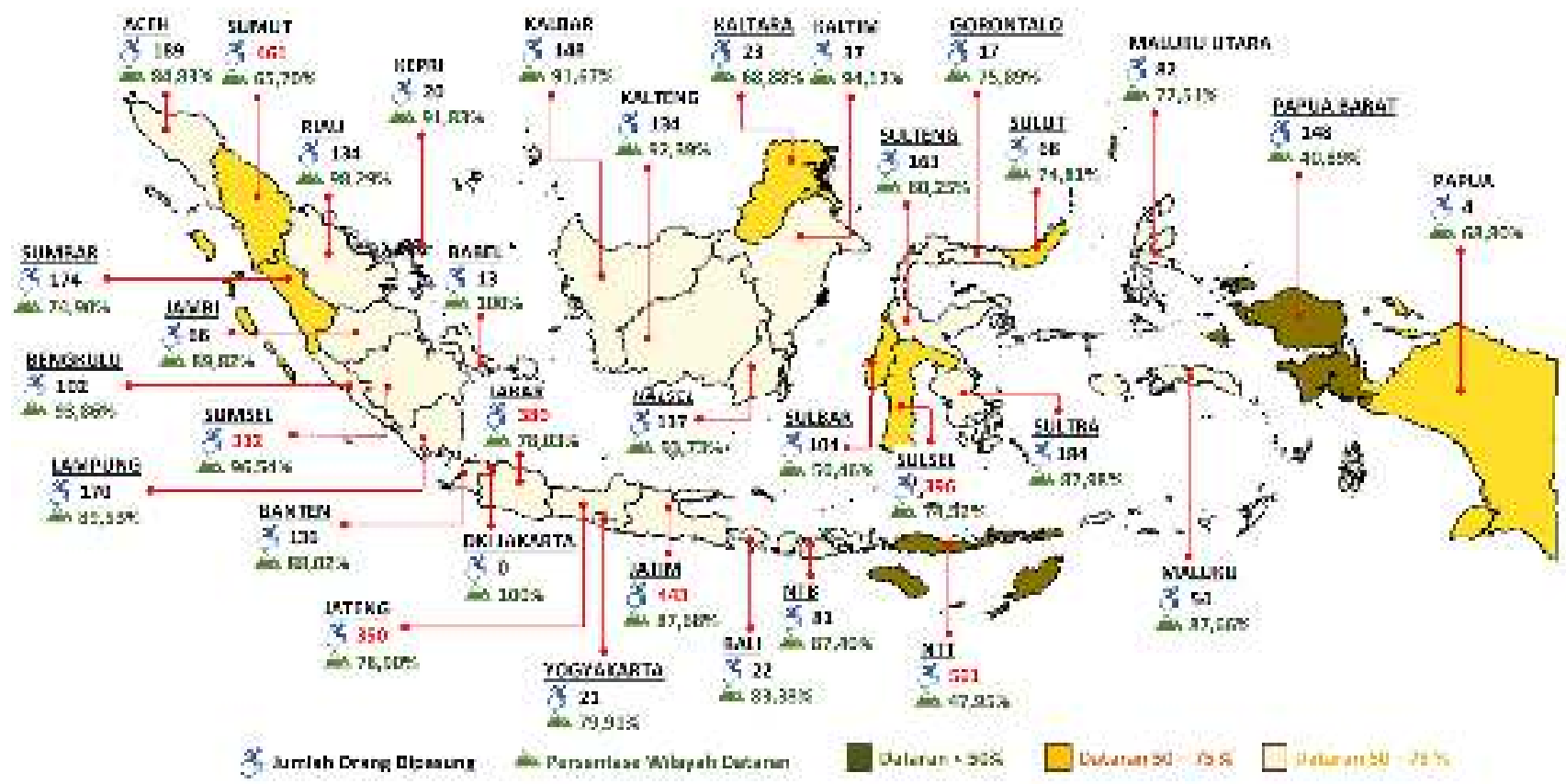

Gambar 4. Jumlah Orang Dipasung dan Topografi WilayahMenurut ProvinsiTahun 2018

Pemasungan diartikan sebagai segala bentuk pembatasan gerak ODGJ oleh keluarga atau masyarakat yang mengakibatkan hilangnya kebebasan ODGJ, termasuk hilangnya hak atas pelayanan kesehatan untuk membantu pemulihan.(Kementerian Kesehatan Republik Indonesia, 2017). Gambar 4 menunjukkan jumlah orang dipasung dan topografi wilayah pada tahun 2018 di Indonesia menurut provinsi. Provinsi dengan jumlah pemasungan terbesar berada di provinsi NTT sebanyak 561 orang. Provinsi lain yang banyak melakukan tindakan pemasungan yaitu Sumatera Utara (461 orang); Jawa Timur (443 orang); Sulawesi Selatan (396 orang); Jawa Barat (380 orang); Jawa Tengah (350 orang); dan Sumatera Selatan (332 orang). Dua provinsi dengan jumlah pasung terkecil yaitu Papua (4 orang) dan DKI Jakarta (tidak ada). Jumlah ini memiliki pola yang sama dengan jumlah penyandang cacat mental pada Gambar 3.

Perbedaan hanya terjadi di Provinsi Sumatera Selatan dimana jumlah penyandang cacat mental sebanyak 9.009 orang dengan prevalensi cacat mental sebesar $0,11 \%$ dan kasus pemasungan sebanyak 332 orang. Sementara provinsi Aceh yang memiliki jumlah penyandag cacat mental sebanyak 13.189 orang dengan prevalensi sebesar $0,25 \%$, menunjukkan angka pemasungan yang tidak terlalu besar. Program Aceh Free Pasung tahun 2010 menjadi salah satu solusi yang dapat memberikan informasi serupa bagi wilayah berpenghasilan rendah agar memberi perhatian lebih terhadap kasus pemasungan pada penyandang cacat mental (Puteh, Marthoenis, \& Minas, 2011).

Wilayah yang memiliki mayoritas wilayah bukan di daerah dataran berdasarkan topografi, memiliki kecenderungan jumlah cacat mental yang cukup besar. Provinsi NTT memiliki wilayah yang sebagian besar berada di lereng/puncak memiliki jumlah kasus cacat mental yang cukup 
besar dan prevalensi cacat mental tertinggi. Kesulitan geografis yang disebabkan oleh wilayah perdesaan di puncak juga membuat kasus pemasungan di NTT menjadi tinggi, dimana 1 dari 19 orang yang cacat mental dipasung. Provinsi Papua Barat dengan struktur topografi yang sama memiliki kasus pemasungan sebanyak 148 orang di antara 2.430 penyandang cacat mental. Artinya 1 dari 16 orang dengan cacat mental dipasung di Papua Barat.

Wilayah Sumatera Utara, Sumatera Barat dan Sulawesi Selatan yang memiliki wilayah perdesaan yang mayoritas berada di lembah, juga memiliki kasus cacat mental yang cukup besar dibandingkan provinsi lainnya. Sementara kasus pemasungan juga banyak terjadi di wilayah yang didominasi oleh lembah, seperti di Sumatera Utara dan Sulawesi Selatan.

\subsection{Analisis Regresi}

Tabel 1. Output padaPengujian Parameter dengan Menggunakan MetodeRegresi OLS Antara Variabel Cacat Mental dan Determinan Sosial Kesehatan Mental

\begin{tabular}{|c|c|c|c|c|c|c|c|c|c|c|}
\hline \multirow{3}{*}{ No } & \multirow{3}{*}{\multicolumn{2}{|c|}{$\begin{array}{l}\text { Variabel Independen } \\
\text { (Determinan Sosial) }\end{array}$}} & \multicolumn{7}{|c|}{ Variabel Dependen (Kesehatan Mental) } & \\
\hline & & & \multicolumn{2}{|l|}{$Y_{1}:$} & \multicolumn{2}{|l|}{$\mathbf{Y}_{2}:$} & \multicolumn{2}{|l|}{$Y_{3}:$} & \multicolumn{2}{|l|}{$Y_{4}:$} \\
\hline & & & \multicolumn{2}{|c|}{ Tuna Grahita } & \multicolumn{2}{|l|}{$\begin{array}{l}\text { Tuna } \\
\text { Laras }\end{array}$} & \multicolumn{2}{|c|}{ Cacat Ganda } & \multicolumn{2}{|l|}{ Pasung } \\
\hline \multirow[t]{2}{*}{1} & \multirow{2}{*}{\multicolumn{2}{|c|}{ Konstanta }} & 1.6288 & $*$ & 0.8911 & $*$ & 0.2496 & $*$ & 0.0163 & * \\
\hline & & & $(0.0414)$ & & $(0.0315)$ & & $(0.0203)$ & & $(0.0041)$ & \\
\hline \multirow[t]{2}{*}{2} & $\mathrm{D}_{1}$ & Mata Pencaharian Utama & -0.1544 & $*$ & -0.0450 & & -0.0637 & * & 0.0383 & $*$ \\
\hline & & (1. Pertanian ; 0. Lainnya) & $(0.0385)$ & & $(0.0293)$ & & $(0.0189)$ & & $(0.0038)$ & \\
\hline \multirow[t]{2}{*}{3} & $\mathrm{D}_{2}$ & Topografi Wilayah & -0.1091 & $*$ & -0.0760 & $*$ & 0.0240 & & 0.0183 & $*$ \\
\hline & & $\begin{array}{l}\text { (1. Lembah/Lereng/Puncak ; } \\
0 . \text { Daratan) }\end{array}$ & $(0.0306)$ & & $(0.0233)$ & & $(0.015)$ & & $(0.003)$ & \\
\hline \multirow[t]{2}{*}{4} & $\mathrm{D}_{3}$ & Letak Wilayah Terhadap Hutan & -0.4739 & * & -0.3309 & $*$ & -0.0684 & $*$ & -0.0051 & $* * *$ \\
\hline & & (1. Di dalam/di sekitar ; 0. Di luar) & $(0.0285)$ & & $(0.0217)$ & & $(0.014)$ & & $(0.0028)$ & \\
\hline \multirow[t]{2}{*}{5} & $\mathrm{D}_{4}$ & Keberadaan Permukiman Kumuh & 0.5562 & * & 0.2363 & $*$ & 0.1735 & * & 0.0076 & \\
\hline & & (1. Ada ; 0. Tidak Ada) & $(0.0485)$ & & $(0.0369)$ & & $(0.0238)$ & & $(0.0048)$ & \\
\hline \multirow[t]{2}{*}{6} & $\mathrm{D}_{5}$ & Keberadaan Pencemaran Air & 0.3207 & $*$ & 0.2583 & $*$ & 0.0569 & $*$ & 0.0098 & * \\
\hline & & (1. Ada ; 0. Tidak Ada) & $(0.0309)$ & & $(0.0235)$ & & $(0.0151)$ & & $(0.003)$ & \\
\hline \multirow[t]{2}{*}{7} & $\mathrm{D}_{6}$ & Keberadaan Pencemaran Tanah & 0.1250 & $* * *$ & 0.0463 & & 0.0722 & $* * *$ & 0.0111 & \\
\hline & & (1. Ada ; 0. Tidak Ada) & $(0.0755)$ & & $(0.0574)$ & & $(0.037)$ & & $(0.0075)$ & \\
\hline \multirow[t]{2}{*}{8} & $\mathrm{D}_{7}$ & Keberadaan Pencemaran Udara & 0.6171 & $*$ & 0.3538 & $*$ & 0.0694 & $*$ & 0.0012 & \\
\hline & & (1. Ada ; 0. Tidak Ada) & $(0.0395)$ & & $(0.0301)$ & & $(0.0194)$ & & $(0.0039)$ & \\
\hline \multirow[t]{2}{*}{9} & $\mathrm{D}_{8}$ & $\begin{array}{ll}: & \text { Keberadaan PSK }\end{array}$ & 0.0070 & & -0.1116 & & 0.0774 & & 0.0166 & \\
\hline & & (1. Ada ; 0. Tidak Ada) & $(0.1166)$ & & $(0.0887)$ & & $(0.0571)$ & & $(0.0115)$ & \\
\hline \multirow[t]{2}{*}{10} & $\mathrm{D}_{9}$ & Keragaman Suku & 0.1679 & $*$ & 0.1773 & $*$ & 0.0419 & * & -0.0083 & * \\
\hline & & (1. Tidak Ada ; 0. Beragam) & $(0.0275)$ & & $(0.0209)$ & & $(0.0135)$ & & $(0.0027)$ & \\
\hline \multirow[t]{2}{*}{11} & $\mathrm{X}_{1}$ & : Jumlah Penderita Gizi Buruk & 0.0011 & & 0.0020 & $* *$ & 0.0012 & $* * *$ & 0.0005 & $*$ \\
\hline & & & $(0.0013)$ & & $(0.001)$ & & $(0.0007)$ & & $(0.0001)$ & \\
\hline & $\mathrm{X}_{2}$ & : Jumah Fasilitas Kesehatan & 0.3618 & $*$ & 0.1612 & $*$ & 0.1142 & $*$ & 0.0090 & $*$ \\
\hline & & & $(0.0176)$ & & $(0.0134)$ & & $(0.0086)$ & & $(0.0017)$ & \\
\hline \multirow[t]{5}{*}{13} & $\mathrm{X}_{3}$ & : Jumlah Tenaga Kesehatan & 0.0504 & $*$ & 0.0273 & $*$ & 0.0098 & $*$ & 0.0010 & $*$ \\
\hline & & & $(0.0013)$ & & $(0.001)$ & & $(0.0006)$ & & $(0.0001)$ & \\
\hline & Prob & $>\mathrm{F}$ & 0.0000 & & 0.0000 & & 0.0000 & & 0.0000 & \\
\hline & $\mathrm{R}^{2}$ & & 0.0558 & & 0.0293 & & 0.0117 & & 0.0029 & \\
\hline & Adju & sted $\mathrm{R}^{2}$ & 0.0556 & & 0.0292 & & 0.0116 & & 0.0028 & \\
\hline \multicolumn{3}{|c|}{ Keterangan : Observasi $=83.931$; } & $\begin{array}{l}\text { da taraf } 1 \\
\text { ada tara }\end{array}$ & & & & & & & \\
\hline
\end{tabular}


Analisis regresi dalam penelitian ini digunakan untuk mengetahui bagaimana kaitan antara 12 variabel independen terhadap empat variabel dependen yaitu jumlah penyandang tunagrahita, tuna laras, cacat ganda dan jumlah orang dipasung. Variabel $1-10$ merupakan variabel berskala nominal sehingga diolah menjadi dua kategori secara dikotomi yaitu dengan menggunakan variabel dummy. Variabel $11-13$ merupakan variabel berskala rasio sehingga langsung dilakukan regresi terhadap variabel dependen.

Tabel 2. Hasil Pengujian Normalitas dan Homoskedastisitas Terhadap Model yang Terbentuk

\begin{tabular}{|c|c|c|c|c|c|c|c|}
\hline \multirow{3}{*}{ No } & & & \multirow{3}{*}{ Variabel Dependen } & \multirow{2}{*}{\multicolumn{2}{|c|}{$\begin{array}{c}\text { Pengujian Normalitas } \\
\text { Nilai Prob }>\mathbf{z}\end{array}$}} & \multirow{2}{*}{\multicolumn{2}{|c|}{$\begin{array}{c}\begin{array}{c}\text { Pengujian } \\
\text { Heteroskedastisitas }\end{array} \\
\text { Nilai Prob }>\mathrm{z}\end{array}$}} \\
\hline & & & & & & & \\
\hline & & & & $\begin{array}{c}\text { Shapiro } \\
\text { Wilk }\end{array}$ & $\begin{array}{l}\text { Shapiro } \\
\text { Francia }\end{array}$ & Chi2(1) & $\begin{array}{c}\text { Prob }> \\
\text { chi2 }\end{array}$ \\
\hline 1 & Model 1 & $:$ & Tuna Grahita & 0.00000 & 0.00001 & $30.499,99$ & 0.0000 \\
\hline 2 & Model 2 & $:$ & Tuna Laras & 0.00000 & 0.00001 & $37.393,20$ & 0.0000 \\
\hline 3 & Model 3 & $:$ & Cacat Ganda (Fisik dan Mental) & 0.00000 & 0.00001 & $25.389,42$ & 0.0000 \\
\hline 4 & Model 4 & $:$ & Pasung & 0.00000 & 0.00001 & $4.512,68$ & 0.0000 \\
\hline
\end{tabular}

Model yang didapatkan akan data diintepretasikan dengan baik jika memenuhi uji asumsi klasik, agar tercipta model yang BLUE. Asumsi Klasik yang dimaksud adalah:

1. Uji Normalitas

Uji normalitas dilakukan pada setiap model yang terbentuk. Pengujian ini mengharapkan adanya residual yang menyebar secara normal dengan rata-rata 0 dan varians yang identik $\left(\varepsilon \sim N\left(0, \sigma^{2}\right)\right)$. Uji dilakukan dengan menggunakan uji Saphiro Wilk dan Shapiro Francia, dengan $\alpha$ ditetapkan sebesar $5 \%$.

2. Uji Homoskedastisitas

Uji homoskedastisitas mengharapkan error memiliki variance/ragam yang sama (homogen). Secara matematis dapat dituliskan $\sigma_{\varepsilon_{i}}{ }^{2}={\sigma_{\varepsilon_{j}}}^{2}=\cdots=\sigma_{\varepsilon}{ }^{2}$. Statistik uji yang sering digunakan adalah Breusch-Pagan test. Jika nilai p-value (Probability $>$ chi $^{2}$ ) melebihi $\alpha$ ditetapkan sebesar 5\% maka varians dari residual bersifat homoskedas/homogen.

Pengujian normalitas dan homoskedastisitas menunjukkan hasil yang sama yaitu, residual yang terbentuk tidak menyebar secara normal dan varians yang dihasilkan oleh residual tidak bersifat homogen.

Tabel 3. Hasil Pengujian Multikolienaritas Terhadap Variabel Bebas

\begin{tabular}{|c|c|c|c|c|}
\hline No & & Variabel Independen & VIF & 1/VIF \\
\hline 1 & $\mathrm{D}_{1}$ & : Mata Pencaharian Utama & 1.24 & 0.8041 \\
\hline 2 & $\mathrm{D}_{2}$ & : Topografi Wilayah & 1.16 & 0.8593 \\
\hline 3 & $\mathrm{D}_{3}$ & : Letak Wilayah Terhadap Hutan & 1.14 & 0.8742 \\
\hline 4 & $\mathrm{D}_{4}$ & : Keberadaan Permukiman Kumuh & 1.10 & 0.9129 \\
\hline 5 & $\mathrm{D}_{5}$ & : Keberadaan Pencemaran Air & 1.13 & 0.8830 \\
\hline
\end{tabular}




\begin{tabular}{ccllll}
6 & $\mathrm{D}_{6}$ & $:$ & Keberadaan Pencemaran Tanah & 1.08 & 0.9273 \\
7 & $\mathrm{D}_{7}$ & $:$ Keberadaan Pencemaran Udara & 1.09 & 0.9138 \\
8 & $\mathrm{D}_{8}$ & $:$ Keberadaan PSK & 1.01 & 0.9879 \\
9 & $\mathrm{D}_{9}$ & $:$ Keragaman Suku & 1.08 & 0.9230 \\
10 & $\mathrm{X}_{1}$ & $:$ & Jumlah Penderita Gizi Buruk & 1.00 & 0.9996 \\
11 & $\mathrm{X}_{2}$ & $:$ Jumah Fasilitas Kesehatan & 1.14 & 0.8780 \\
12 & $\mathrm{X}_{3}$ & $:$ Jumlah Tenaga Kesehatan & 1.23 & 0.8119 \\
\hline
\end{tabular}

\section{Uji Multikolinearitas}

Uji asumsi ini mengharapkan tidak terjadi korelasi linear yang erat antar variabel bebas. Uji ini dapat dilakukan dengan menggunakan statistik uji Variance Inflating Factor (VIF). Nilai VIF hasil pengolahan yang melebihi 10 memberikan indikasi adanya multikolinearitas yang erat. Hasil pengujian pada tabel 4 menunjukkan bahwa tidak ditemukan adanya multikolinearitas yang erat antar variabel bebas dalam model yang telah terbentuk.

Uji asumsi klasik yang telah dilakukan memberikan hasil bahwa keempat model yang terbentuk tidak memenuhi dua asumsi yaitu asumsi normalitas dan homoskedastisitas. Pelanggaran ini akan membuat hasil estimasi parameter yang dilakukan menjadi tidak akurat. Kedua masalah tersebut perlu diatasi dengan menggunakan model Robust Standard Error.

Tabel 4. Output pada Pengujian Parameter dengan Menggunakan MetodeRegresi OLS dengan Penggunaan Robust Standard ErrorAntara Variabel Cacat Mental dan Determinan Sosial Kesehatan Mental

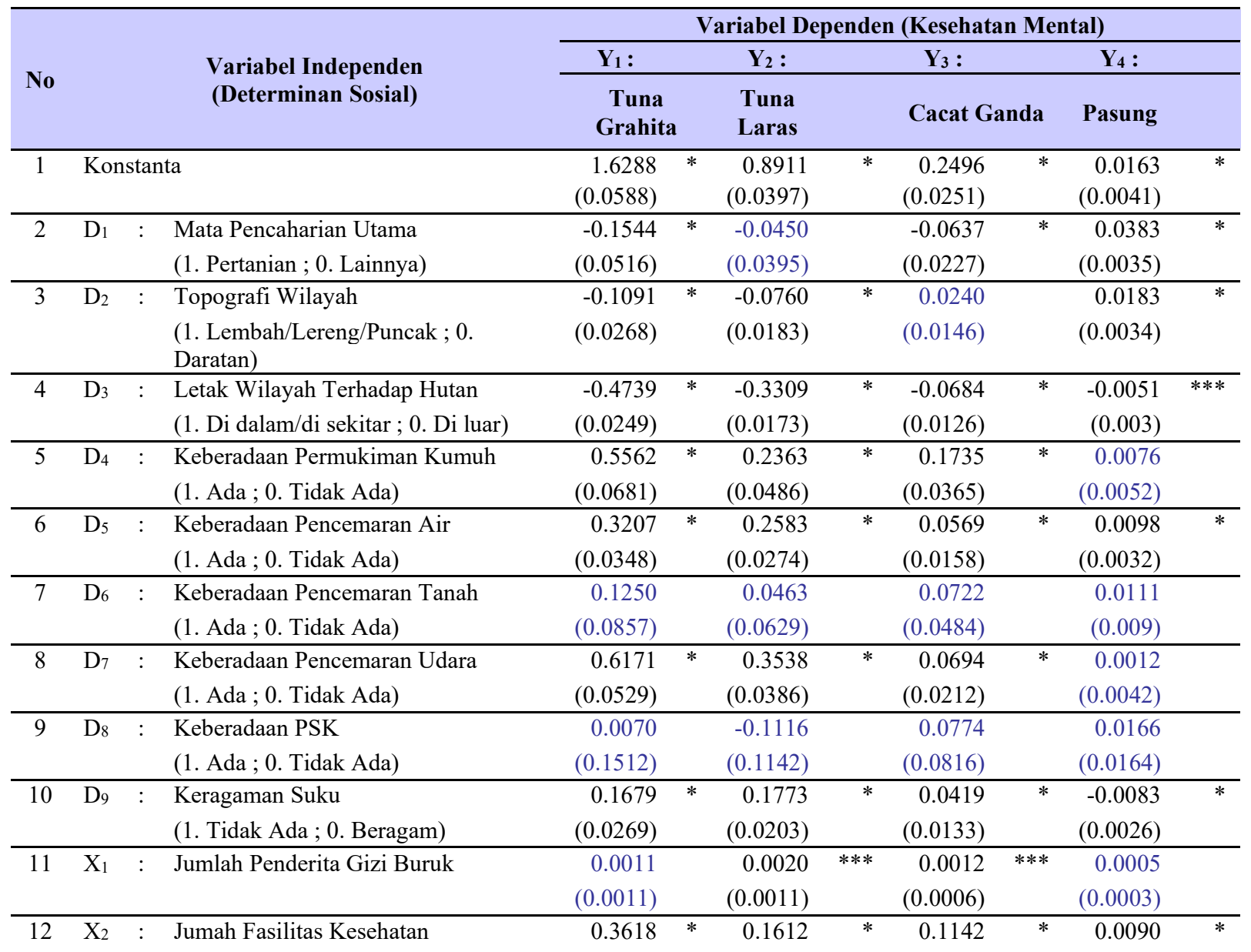




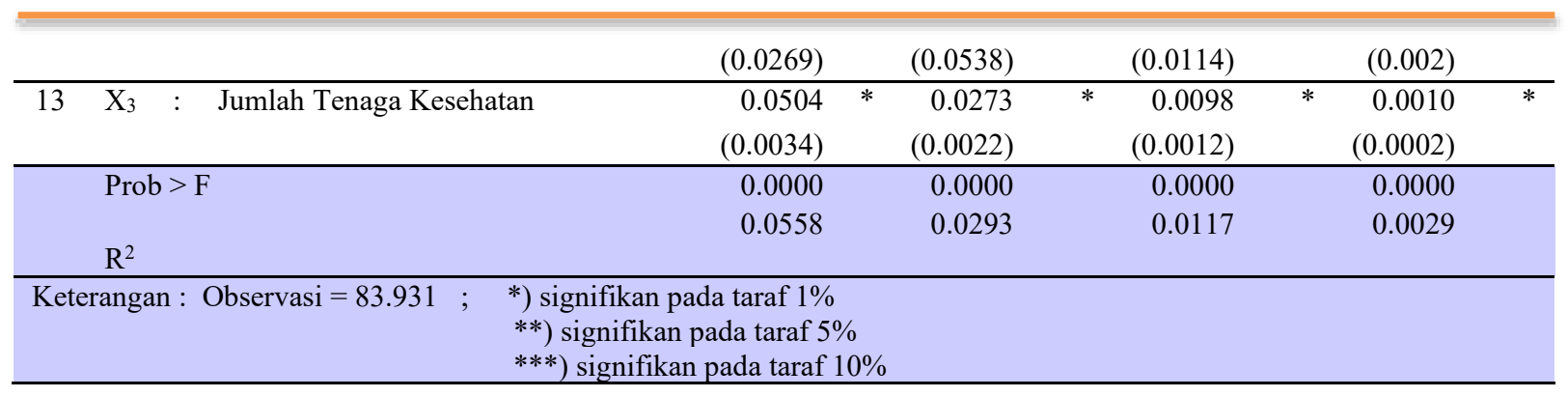

Pengujian parameter dengan menggunakan model Robust Standard Error akan menghasilkan model terbaik. Analisis yang dapat dilakukan adalah sebagai berikut:

1) Keseluruhan model menghasilkan nilai Prob $>$ F kurang dari $\alpha=5 \%$, yang berarti seluruh model telah signifikan atau secara serentak variabel independen berpengaruh terhadap variabel dependen.

2) Secara umum, variabel dummy pencemaran tanah dan keberadaan PSK tidak berpengaruh secara signifikan bagi keempat variabel cacat mental.

3) Variabel mata pencaharian berhubungan positif dengan jumlah pemasungan, namun berhubungan negatif dengan kejadian cacat mental.

4) Wilayah yang berada di lembah/lereng/puncak berhubungan negatif dengan jumlah tunagrahita dan tunalaras, sementara berhubungan positif dengan kejadian cacat ganda dan jumlah pemasungan. Sementara letak wilayah di dalam/sekitar hutan berhubungan negatif dengan penduduk cacat mental. Kedua variabel geografis ini kurang dapat memberikan gambaran sebagai faktor yang mempengaruhi jumlah penduduk cacat mental dan pemasungan. Variabel lingkungan fisik kurang memberikan kontribusi bagi kasus gangguan kesehatan mental (Ma, Li, Kwan, \& Chai, 2018).

5) Keberadaan permukiman kumuh akan berhubungan positif dengan jumlah cacat mental dan kejadian pasung. Temuan ini sesuai dengan penelitian sebelumnya dimana lingkungan tempat tinggal kumuh memiliki hubungan dengan kejadian cacat dan umur ibu berhubungan dengan Kejadian down syndrome(Harahap \& Salimar, 2014).

6) Pencemaran air, tanah dan udara terbukti berhubungan positif dengan jumlah cacat mental. Pencemaran baik langsung maupun tidak langsung yang dapat membahayakan kesehatandan kesejahteraan manusia. Beberapa penelitian sebelumnya mengkonfirmasi bahwa memang terdapat hubungan yang kuat antara polusi dengan kejadian cacat mental (Chen, Oliva, \& Zhang, 2018; Dzhambov et al., 2018; Roberts et al., 2019).

7) Keberadaan PSK akan menambah kemungkinan jumlah cacat mental, kecuali pada tunalaras. Tidak adanya keragaman suku menambah jumlah gangguan cacat mental. Suku yang seragam menaikkan kemungkinan adanya interracial marriage atau incest marriage. Pernikahan sedarah akan memberikan kemungkinan keturunan yang memiliki kelainan cacat mental (Baird \& McGillivray, 1982; Celbis, Altın, Ayaz, Börk, \& Karatoprak, 2019). Sementara, jumlah penderita gizi buruk berhubungan positif kemungkinan jumlah cacat mental. 
8) Jumlah fasilitas kesehatan dan tenaga kesehatan berhubungan positif dengan jumlah penyandang cacat mental. Masyarakat dengan penghasilan rendah akan lebih mudah mengakses fasilitas kesehatan mental melalui sarana rawat jalan, sedangkan masyarakat di perkotaan akan lebih memilih akses rawat inap. Sumber daya yang memadai diperlukan dalam penempatan fasilitas kesehatan pada komunitas penghasilan rendah tersebut (Cummings, Allen, Clennon, Ji, \& Druss, 2017).

Beberapa variabel yang digunakan memberikan hasil yang bervariasi terhadap variabel dependen. Sementara beberapa variabel lain memberikan hasil yang signifikan. Sehingga dapat disimpulkan secara umum bahwa beberapa variabel yang digunakan dalam penelitian ini memang memiliki hubungan dan berpengaruh terhadap kejadian cacat mental.

\section{KESIMPULAN DAN SARAN}

Penelitian ini memiliki hasil yang sama dengan beberapa penelitian sebelumnya. Kesimpulan yang bisa didapatkan dari penelitian empiris ini adalah sebagai berikut:

1) Sistem Informasi Geografis melalui peta wilayah menunjukkan bahwa kepadatan penduduk akan menghasilkan jumlah cacat mental yang lebih tinggi.

2) Prevalensi cacat mental menyebar di seluruh wilayah Indonesia. Wilayah Sulawesi memiliki prevalensi cacat mental yang sedang di setiap wilayah.

3) Kejadian pemasungan memiliki pola yang sama dengan jumlah cacat mental, dimana kejadian terbanyak berada di Provinsi NTT.

4) Semakin sulit topografi wilayah maka akan semakin banyak kasus pemasungan yang terjadi, yaitudi wilayah Provinsi NTT dan Papua Barat.

5) Metode OLS dengan menggunakan robust standart error menunjukkan bahwa pengaruh lingkungan fisik seperti topografi tidak terlalu berpengaruh pada jumlah cacat mental, namun pencemaran dan permukiman kumuh berkorelasi terhadap jumlah cacat mental.

Saran bagi penelitian selanjutnya yaitu perlu dikembangkan lagi agar penelitian dapat menjadi penelitian panel ataupun time series dengan menggunakan data dengan rentang waktu yang lebih panjang. Penelitian selanjutnya dapat menggunakan variabel-variabel lain yang lebih dapat mencerminkan jumlah kejadian cacat mental berkaitan dengan ekonomi, yaitu jumlah penduduk, pendapatan, sektor lapangan usaha dan sebagainya. Saran bagi pemerintah untuk memberikan perhatian khusus bagi kejadian polusi/pencemaran baik air, tanah maupun udara, sebab penelitian ini telah membuktikan bahwa pencemaran dan pemukiman kumuh berkorelasi dengan jumlah cacat mental.

\section{DAFTAR PUSTAKA}

Baird, P. A., \& McGillivray, B. (1982). Children of incest. The Journal of Pediatrics, 101(5), 854-857. https://doi.org/10.1016/S0022-3476(82)80347-8

Becker, G. S., Murphy, K. N., \& Tamura, R. F. (1990). Human Capital, Fertility, and Economic Growth. NBER Working Paper, 3414(August).

Bhattacharya, J., Hyde, T., \& Tu, P. (2014). Health Economics. New York: Palgrave Macmillan.

Bloom, D. E., Cafiero, E. T., Jané-Llopis, E., Abrahams-Gessel, S., Bloom, L. R., Fathima, S., 
... Weinstein, C. (2011). The Global Economic Burden of Noncommunicable Diseases. Retrieved from http://www3.weforum.org/docs/WEF_Harvard_HE_GlobalEconomicBurdenNonCommun icableDiseases_2011.pdf

Bosqui, T. J., Maguire, A., Kouvonen, A., Wright, D., Donnelly, M., \& O’Reilly, D. (2017). Ethnic density and risk of mental ill health - The case of religious sectarianism in Northern Ireland: A population data linkage study. Health and Place, 47(September 2016), 29-35. https://doi.org/10.1016/j.healthplace.2017.06.010

Bucciarelli, E., Odoardi, I., \& Muratore, F. (2010). What role for education and training in technology adoption under an advanced socio-economic perspective? Procedia - Social and Behavioral Sciences, 9, 573-578. https://doi.org/10.1016/j.sbspro.2010.12.199

Burns, J. K. (2015). Poverty, inequality and a political economy of mental health. Epidemiology and Psychiatric Sciences, 24(2), 107-113. https://doi.org/10.1017/S2045796015000086

Celbis, O., Altın, İ., Ayaz, N., Börk, T., \& Karatoprak, S. (2019). Evaluation of Incest Cases : 4Years Retrospective Study. Journal of Child Sexual Abuse. https://doi.org/10.1080/10538712.2019.1634664

Chen, S., Oliva, P., \& Zhang, P. (2018). Air Pollution and Mental Health: Evidence from China. NBER Working Paper Series, (24686), 1-53. https://doi.org/10.2139/ssrn.3028930

Cummings, J. R., Allen, L., Clennon, J., Ji, X., \& Druss, B. G. (2017). Geographic access to specialty mental health care across high-and low-income US communities. JAMA Psychiatry, 74(5), 476-484. https://doi.org/10.1001/jamapsychiatry.2017.0303

Denison, E. F. (1962). Education, Economic Growth, and Gaps in Information. The Journal of Political Economy, LXX No.5 ((October), 124-128. Retrieved from http://www.nber.org/books/univ62-3

Dewi, K. S. (2012). BUKU AJAR KESEHATAN MENTAL (I). Semarang: UPT UNDIP Press Semarang.

Dzhambov, A. M., Markevych, I., Tilov, B., Arabadzhiev, Z., Stoyanov, D., Gatseva, P., \& Dimitrova, D. D. (2018). Pathways linking residential noise and air pollution to mental illhealth in young adults. Environmental Research, 166(June), 458-465. https://doi.org/10.1016/j.envres.2018.06.031

Fortney, J., Rost, K., \& Warren, J. (2000). Comparing alternative methods of measuring geographic access to health services. Health Services and Outcomes Research Methodology, 1(2), 173-184. https://doi.org/10.1023/A:1012545106828

Funk, M., Drew, N., Freeman, M., Faydi, E., Ommeren, M. Van, \& Kettaneh, A. (2010). Mental Health And Development: Targeting people with mental health conditions as a vulnerable group. Geneva.

Funk, M., Drew, N., \& Knapp, M. (2012). Mental health , poverty and development. Journal of Public Mental Health, 11(4), 166-185. https://doi.org/10.1108/17465721211289356

Gresenz, C. R., \& Sturm, R. (2004). Mental Health And Employment Transitions. Research in Human Capital and Development, Vol. 15, pp. 95-108. https://doi.org/10.1016/S0194- 


\section{0(04)15006-3}

Grossman, M. (1972). On the Concept of Health Capital and the Demand for Health. Journal of Political Economy, 80(2), 223-255. https://doi.org/10.7312/gros17812-004

Harahap, H., \& Salimar. (2014). Kejadian Cacat Pada Anak Usia 24-59 Bulan Dan Faktor-Faktor Yang Berkaitan, Riskesdas 2010. Indonesian Journal of Health Ecology, 14(3), 206-217.

Isnaini, Abdullah, A., \& Saputra, I. (2019). Kerugian Ekonomi Akibat Schizophrenia Pada Penderita Rawat Inap Di Rumah Sakit Jiwa Aceh Tahun 2016 Dan Estimasi Nilai Kerugian Pada Tahun Berikutnya. 4(2), 313-322.

Janz, N. K., \& Becker, M. H. (1984). The Health Belief Model: A Decade Later. Health Education Quarterly, 11(1), 1-47. https://doi.org/10.1177/109019818401100101

Kementerian Kesehatan Republik Indonesia. (2017). Peraturan Menteri Kesehatan Republik Indonesia Nomor 54 Tahun 2017 Tentang Penanggulangan Pemasungan Pada Orang Dengan Gangguan Jiwa. Retrieved from https://peraturan.bpk.go.id/Home/Details/112230/permenkes-no-54-tahun-2017

Laird, J. T. (1973). Mental health and population density. Journal of Psychology: Interdisciplinary and Applied, 85(2), 171-177. https://doi.org/10.1080/00223980.1973.9915647

Layard, R. (2016). The economics of mental health. (January), 1-10. https://doi.org/10.15185/izawol.321

Ma, J., Li, C., Kwan, M. P., \& Chai, Y. (2018). A multilevel analysis of perceived noise pollution, geographic contexts and mental health in Beijing. International Journal of Environmental Research and Public Health, 15(7), 1-18. https://doi.org/10.3390/ijerph15071479

Milner, A., Krnjacki, L., Butterworth, P., Kavanagh, A., \& LaMontagne, A. D. (2015). Does disability status modify the association between psychosocial job quality and mental health? A longitudinal fixed-effects analysis. Social Science and Medicine, 144, 104-111. https://doi.org/10.1016/j.socscimed.2015.09.024

Mizunoya, S., \& Mitra, S. (2013). Is There a Disability Gap in Employment Rates in Developing Countries? World Development, 28-43. https://doi.org/10.1016/j.worlddev.2012.05.037

Nicholson, W., \& Snyder, C. (2012). Microeconomic Theory: Basic Principles and Extensions, Eleventh Edition. South-Western: Cengage Learning.

Puteh, I., Marthoenis, M., \& Minas, H. (2011). Aceh Free Pasung: Releasing the mentally ill from physical restraint. International Journal of Mental Health Systems, 5(10), 1-5. https://doi.org/10.1186/1752-4458-5-10

Rahmanti, A. R., \& Prasetyo, A. K. N. (2012). Sistem informasi geografis: Trend pemanfaatan teknologi informasi untuk bidang terkait kesehatan. Seminar Nasional Informatika Medis III (SNIMed III), (September), 6-12. Retrieved from https://journal.uii.ac.id/snimed/article/view/4086

Ridlo, I. A. (2017, March). Indonesia Darurat Kesehatan Mental? Retrieved from 
https://www.researchgate.net/publication/315754402

Riyanto, D. (2017). Perancangan Sistem Informasi Geografis Untuk Pemetaan Sebaran Pasien Keterbelakangan Mental Di Kabupaten Ponorogo. Multitek Indonesia Jurnal Ilmiah, 11(2), 114-123.

Roberts, S., Arseneault, L., Barratt, B., Beevers, S., Danese, A., Odgers, C. L., ... Fisher, H. L. (2019). Exploration of NO 2 and PM 2.5 air pollution and mental health problems using high-resolution data in London-based children from a UK longitudinal cohort study. Psychiatry Research, 272(2), 8-17. https://doi.org/10.1016/j.psychres.2018.12.050

Rong, Y., Tian, C., Li, L., \& Zheng, X. (2020). Labor hiring and stock return: A model and new evidence from China. Pacific Basin Finance Journal, 59(December 2019), 101256. https://doi.org/10.1016/j.pacfin.2019.101256

Santerre, R. E., \& Neun, S. P. (2010). Health Economics: Theory, Insights, and Industry Studies Fifth Edition. In South-Western, CENGAGE Learning. https://doi.org/10.1007/978-3-54068540-1

Schultz, T. W. (1961). Investment in Human Capital. The American Economic Review, 51(1), 117. Retrieved from https://www.jstor.org/stable/1818907

Schweitzer, L., \& Su, W. H. (1977). Population density and the rate of mental illness. American Journal of Public Health, 67(12), 1165-1172. https://doi.org/10.2105/AJPH.67.12.1165

Trautmann, S., Rehm, J., \& Wittchen, H. U. (2016). The economic costs of mental disorders: Do our societies react appropriately to the burden of mental disorders? In EMBO Reports (Vol. 17). https://doi.org/10.15252/embr.201642951

United Nations Development Programme. (2019). Human Development Report 2019: Beyond income , beyond averages , beyond today. Retrieved from http://hdr.undp.org/sites/default/files/hdr2019.pdf

Vedeler, J. S. (2014). Disabled persons' job interview experiences: Stories of discrimination, uncertainty and recognition. Disability and Society, 29(4), 597-610. https://doi.org/10.1080/09687599.2013.831748

Williams, D. G. (1994). Population density and mental illness. Journal of Social Psychology, 134(4), 545-546. https://doi.org/10.1080/00224545.1994.9712205

World Health Organization, \& Calouste Gulbenkian Foundation. (2014). Social determinants of mental health. In Global Mental Health: Prevention and Promotion. https://doi.org/10.1007/978-3-319-59123-0_4 